\title{
Escherichia coli avoids high dissolved oxygen stress by activation of SoxRS and manganese- superoxide dismutase
}

\author{
Antonino Baez and Joseph Shiloach*
}

\begin{abstract}
Background: High concentrations of reactive oxygen species (ROS) were reported to cause oxidative stress to $E$. coli cells associated with reduced or inhibited growth. The high ROS concentrations described in these reports were generated by exposing the bacteria to $\mathrm{H}_{2} \mathrm{O}_{2}$ and superoxide-generating chemicals which are non-physiological growth conditions. However, the effect of molecular oxygen on oxidative stress response has not been evaluated. Since the use of oxygen-enriched air is a common strategy to support high density growth of E. coli, it was important to investigate the effect of high dissolved oxygen concentrations on the physiology and growth of $E$. coli and the way it responds to oxidative stress.

Results: To determine the effect of elevated oxygen concentrations on the growth characteristics, specific gene expression and enzyme activity in E. coli, the parental and SOD-deficient strain were evaluated when the dissolved oxygen $\left(\mathrm{dO}_{2}\right.$ ) level was increased from 30\% to 300\%. No significant differences in the growth parameters were observed in the parental strain except for a temporary decrease of the respiration and acetate accumulation profile. By performing transcriptional analysis, it was determined that the parental strain responded to the oxidative stress by activating the SoxRS regulon. However, following the $\mathrm{dO}_{2}$ switch, the SOD-deficient strain activated both the SoxRS and OxyR regulons but it was unable to resume its initial growth rate.

Conclusion: The transcriptional analysis and enzyme activity results indicated that when $E$. coli is exposed to $\mathrm{dO}_{2}$ shift, the superoxide stress regulator SoxRS is activated and causes the stimulation of the superoxide dismutase system. This enables the $E$. coli to protect itself from the poisoning effects of oxygen. The OxyR protecting system was not activated, indicating that $\mathrm{H}_{2} \mathrm{O}_{2}$ did not increase to stressing levels.
\end{abstract}

Keywords: Oxidative stress, ROS, SoxS, Catalase activity, SOD activity

\section{Background}

High density growth of E. coli is the preferred method for maximizing volumetric production yield of bacterial biomass and recombinant protein production [1,2]. Due to the high oxygen demand of such cultures, an efficient way to maintain aerobic growth conditions is to increase the oxygen concentration in the air supply by mixing the sparging air with pure oxygen [3-5]. In most cases, the oxygen concentration in the air inlet is increased from $20 \%$ to $68 \%$ [6] and in some cases as high as $100 \%$. Previous research reported that oxidative stress created by

\footnotetext{
* Correspondence: yossi@nih.gov

Biotechnology Core Laboratory, National Institute of Diabetes and Digestive and Kidney Diseases, National Institutes of Health, Bethesda, MD 20892, USA
}

exposing E. coli to $\mathrm{H}_{2} \mathrm{O}_{2}$ and superoxide-generating chemicals was found to be detrimental to the bacterial growth [7-12]. However, the effects of high concentration of molecular oxygen on the bacterial physiological and molecular response either in shake flask growth or at high density growth conditions in bioreactors are unknown.

During its biological reduction to water through respiration, molecular oxygen is generating reactive oxygen species (ROS) such as superoxide anion $\left(\mathrm{O}_{2}^{-}\right)$, hydrogen peroxide $\left(\mathrm{H}_{2} \mathrm{O}_{2}\right)$, and hydroxyl radicals $\left(\mathrm{HO}^{*}\right)$ [13-15]. High levels of ROS are known to be stress conditions for E. coli causing irreversible damage to cellular components $[15,16]$. To prevent this, $E$. coli is equipped with a defense mechanism regulated by the SoxRS and OxyR

\section{Biomed Central}

(c) 2013 Baez and Shiloach; licensee BioMed Central Ltd. This is an Open Access article distributed under the terms of the Creative Commons Attribution License (http://creativecommons.org/licenses/by/2.0), which permits unrestricted use, distribution, and reproduction in any medium, provided the original work is properly cited. 
regulons $[7,15,17,18]$. At normal growth conditions, SoxR is produced in an inactivated (reduced) form, but when exposed to superoxide or redox-cycling drugs, SoxR is activated together with simultaneous activation of the the soxS gene $[8,9,19]$. The SoxS protein is a secondary transcription factor that activates the expression of the following genes: $\operatorname{sod} A, \operatorname{acn} A$, fum $C$, $m i c F$, and $z w f$, replacing sensitive enzymes such as aconitase $B$ and fumarases A and $\mathrm{B}$ with the oxygen resistant isozymes aconitase $\mathrm{A}$ and fumarase $\mathrm{C}$ [20-23]. The OxyR regulon is mainly activated by $\mathrm{H}_{2} \mathrm{O}_{2}$, enhancing the transcription of a set of genes that increase hydrogen peroxide resistance. These include the katG, ahpCF, gor, grxA, trxC and OxyS genes $[7,10,15]$.

The purpose of this work was to evaluate the effect of elevated oxygen concentration on the growth characteristics, enzyme activities, and expression of genes related to the SoxRS and OxyR regulons in E. coli growing in bioreactors. The findings explain the bacterial defense mechanism to high molecular oxygen concentrations in bioreactors.

\section{Results}

Effect of $300 \%$ oxygen saturation on growth, respiration and acetate production of $E$. coli MG1655

The effect of dissolved oxygen $\left(\mathrm{dO}_{2}\right)$ concentration of $300 \%$ air saturation on the growth, respiration, glucose consumption and acetate production of E. coli $\mathrm{K}$ strain (MG1655) was studied in batch and chemostat cultures. The results of the batch growth are summarized in Figure 1 and Table 1 and those of the chemostat cultures in Figure 2 and Table 2. In the batch growth, the cells grew initially at $\mathrm{dO}_{2}$ concentration of $30 \%$ air saturation; when the culture density reached an $\mathrm{OD}_{600}$ of 1 , the $\mathrm{dO}_{2}$ was increased to $300 \%$ and the culture was kept at that level throughout the growth. Following the change in the $\mathrm{dO}_{2}$ concentration, there was a short perturbation in the acetate production profile (Figure 1A), slight decrease in $\mathrm{CO}_{2}$ production and oxygen consumption rates, and an increase in the respiratory quotient (RQ) (Figure 1B). However, no significant changes $(\mathrm{p}=0.05)$ were observed in growth characteristic and overall yield coefficients of the culture (Table 1). To quantify the magnitude of the $\mathrm{dO}_{2}$ effect on the respiration and acetate profile observed in batch cultures, a glucose-limited chemostate culture of E. coli MG1655 operated at steady state $\left(\mathrm{D}=0.5 \mathrm{~h}^{-1}\right)$ was performed. Thirty minutes after the change in the $\mathrm{dO}_{2}$

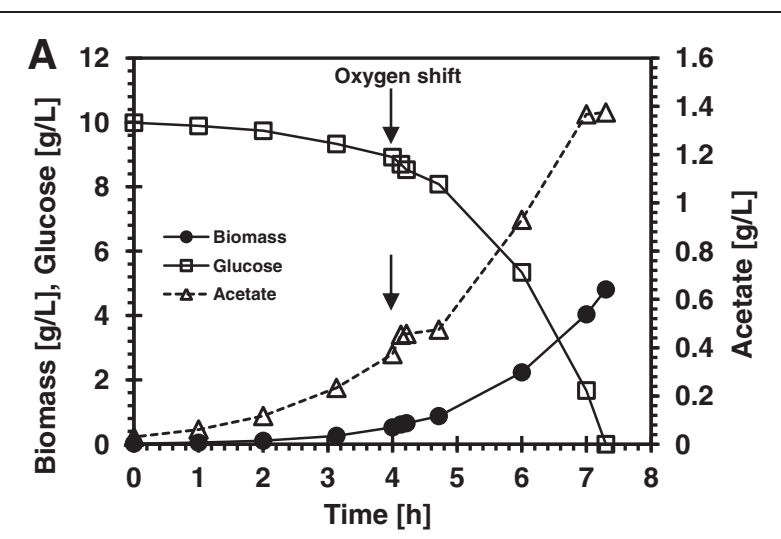

B

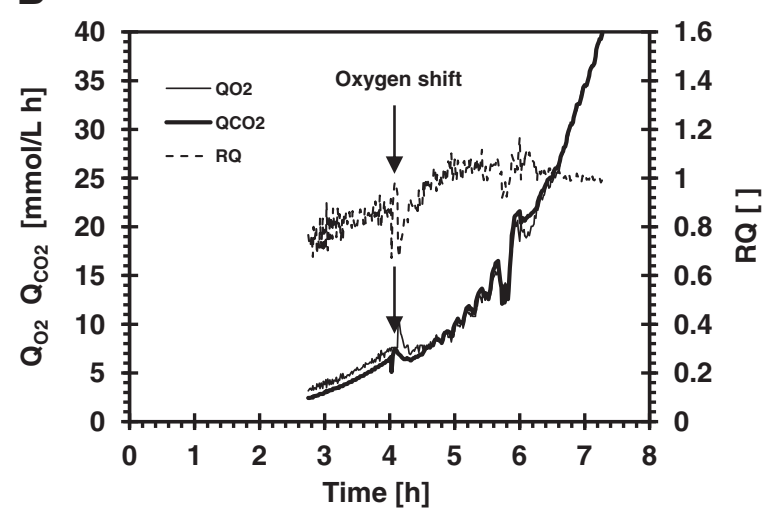

Figure 1 Batch growth of E. coli MG1655 at 30\% and 300\% $\mathbf{d O}_{\mathbf{2}}$. (A) Time course of biomass, glucose and acetate concentrations. (B) Time course of the volumetric oxygen uptake and carbon dioxide formation rates and the respiratory quotient. The arrow indicates when $\mathrm{dO}_{2}$ was increased from 30\% to 300\%.

concentration, acetate concentration decreased from 1.3 to $0.8 \mathrm{~g} / \mathrm{L}$, and it came back to its initial value within an hour; the biomass and the glucose concentrations were unchanged (Figure 2A). Following the $\mathrm{dO}_{2}$ change the oxygen uptake rate decreased by $25 \%$ and carbon dioxide evolution rates decreased by $11 \%$; as was observed in the batch cultures the RQ in the chemostat increased by $19 \%$ (Figure 2B). Table 2 summarizes the growth characteristic of the chemostat culture following the change in $\mathrm{dO}_{2}$ concentration. The increase in RQ suggests that more glucose was directed to the assimilatory pathway for biomass production and correlates with the slight increase in the

Table 1 Batch growth parameter of E. coli MG1655 at dO2 of 30\% and 300\%

\begin{tabular}{|c|c|c|c|}
\hline & Culture exposed to $300 \% \mathrm{dO}_{2}$ & Reference culture $\left(30 \% \mathrm{dO}_{2}\right)$ & \% Change \\
\hline Specific growth rate, $\mu_{1}(\mathrm{~h}-1)$ & $0.684 \pm 0.105$ & $0.717 \pm 0.038$ & -4.6 \\
\hline Glucose uptake rate, $\mathrm{q}_{\mathrm{s}}$ (g/g.h) & $1.34 \pm 0.213$ & $1.45 \pm 0.059$ & -7.6 \\
\hline Biomass yield, $Y_{x / s},(g / g)$ & $0.515 \pm 0.082$ & $0.496 \pm 0.037$ & 3.8 \\
\hline Acetate yield, $\mathrm{Y}_{\mathrm{A} / \mathrm{s}},(\mathrm{g} / \mathrm{g})$ & $0.139 \pm 0.005$ & $0.136 \pm 0.010$ & 2.2 \\
\hline Maximum acetate conc. (g/L) & $1.41 \pm 0.098$ & $1.40 \pm 0.100$ & 0.7 \\
\hline
\end{tabular}



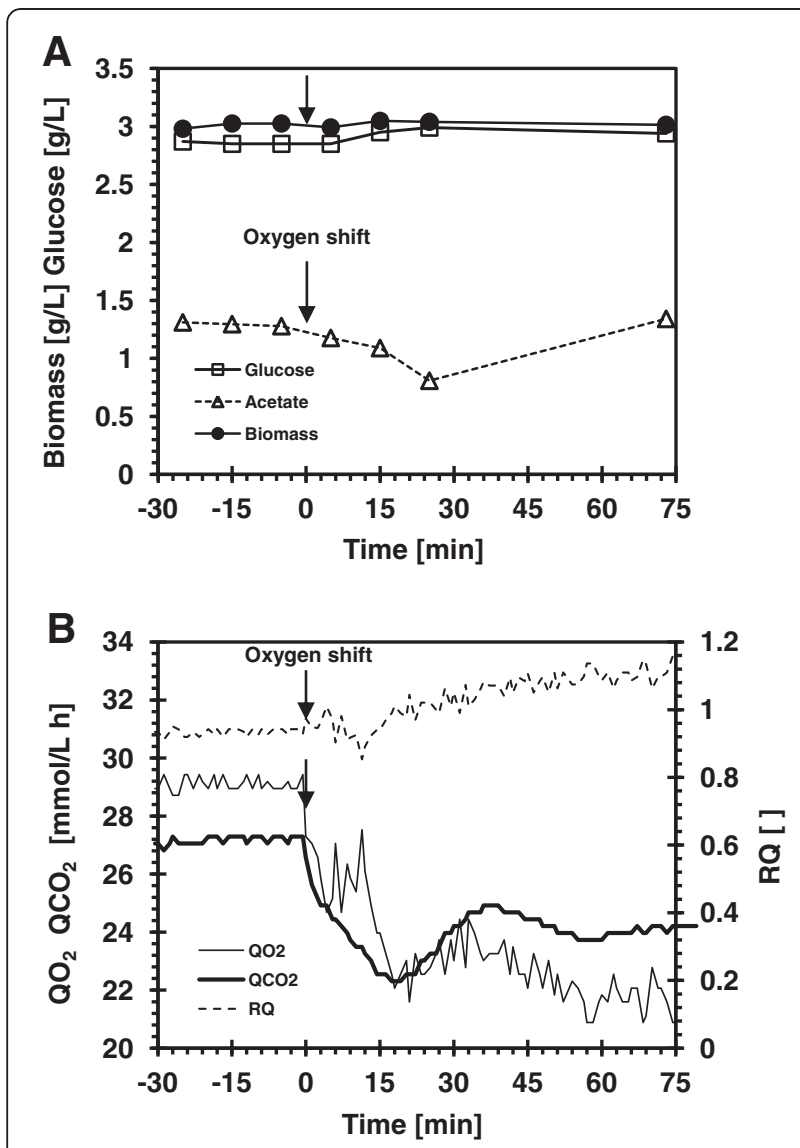

Figure 2 Glucose-limited continuous culture of $E$. coli MG1655 at $\mathbf{3 0} \%$ and $\mathbf{3 0 0} \% \mathrm{dO}_{2}$. (A) Biomass concentration, residual glucose and excreted acetate concentration (B) Volumetric oxygen uptake rate $\left(\mathrm{Q}_{\mathrm{O} 2}\right)$, carbon dioxide formation $\left(\mathrm{Q}_{\mathrm{CO} 2}\right)$ rate, and the respiratory quotient (RQ) profile. The arrow indicates when $\mathrm{dO}_{2}$ was increased from $30 \%$ to $300 \%$.

glucose utilization yield $\mathrm{Y}_{\mathrm{x} / \mathrm{s}}$. The respiration changes observed in the chemostat culture did not affect the growth characteristics of E. coli MG1655, similar to what was observed in the batch culture. Supplying pure oxygen to the chemostat culture did not change further the growth rate but decreased acetate accumulation by $16 \%$ and glucose

Table 2 Continuous culture growth parameters of $E$. coli MG1655 before and after oxygen switch from $30 \%$ dO2 to $300 \%$ dO2

\begin{tabular}{lccc}
\hline & Prior to $\mathbf{O}_{\mathbf{2}}$ switch & After $\mathbf{O}_{\mathbf{2}}$ switch & \% Change \\
\hline $\mathrm{qO}_{2},(\mathrm{mmol} / \mathrm{g} \mathrm{h})$ & 9.65 & 7.25 & -24.9 \\
$\mathrm{qCO}_{2},(\mathrm{mmol} / \mathrm{g} . \mathrm{h})$ & 9.05 & 8.03 & -11.3 \\
$\mathrm{RQ}$ & 0.94 & 1.12 & 19.1 \\
$\mathrm{q}_{\text {acetate, }}(\mathrm{mmol} / \mathrm{g} \mathrm{h})$ & 3.58 & 2.82 & -21.2 \\
$\mathrm{q}_{\mathrm{s},}(\mathrm{mmol} / \mathrm{g} \mathrm{h})$ & 5.10 & 4.96 & -2.7 \\
$\mathrm{Y}_{\mathrm{x} / \mathrm{s},}(\mathrm{g} / \mathrm{g})$ & 0.54 & 0.56 & 3.7 \\
\hline
\end{tabular}

consumption by $10 \%$, (results not shown). The sudden increase in the dissolved oxygen concentration had a minimal effect on E. coli MG1655 growth.

\section{Effect of $300 \%$ oxygen saturation on superoxide dismutase and catalase activity in E. coli MG1655}

The exposure of E. coli MG1655 to $300 \% \mathrm{dO}_{2}$ concentration triggered short perturbation period of decreased respiration, acetate accumulation, and glucose consumption, suggesting limited stress conditions. To investigate further how the bacteria respond to the abrupt dissolved oxygen change, the enzymatic activities of superoxide dismutase (SOD) and catalase were measured. The results for the batch and chemostat cultures are shown in Figure 3. The SOD activity in the batch culture increased 2.3 fold in response to the oxygen shift and decreased towards the end of the growth (Figure 3A). At the same time catalase activity was not affected by the increase in $\mathrm{dO}_{2}$ and was the same throughout the entire cultivation period (Figure 3B). To exclude the effect of varying media composition on SOD and catalase activities, a chemostate culture was performed and the enzymatic activities of SOD and catalase were measured before and after the $\mathrm{dO}_{2}$ shift from 30 to $300 \%$ (Figure $3 \mathrm{C}, \mathrm{D})$. The enzymatic activities were similar to those observed in the batch culture; SOD activity was stimulated by the increase in $\mathrm{dO}_{2}$ concentration but catalase activity stayed the same.

\section{Effect of high oxygen saturation on gene transcription in the SoxRS and OxyR regulons in E. coli MG1655}

Time-course transcription analysis of selected genes associated with SoxRS and OxyR regulons in E. coli MG1655 was conducted following the increase in $\mathrm{dO}_{2}$ concentration; the results are summarized in Figure 4. Forty minutes after the $\mathrm{dO}_{2}$ shift, the transcription of the soxS regulator was 5.3 fold higher, of $\operatorname{sod} A$ (Manganese superoxide dismutase) 3.7 fold higher, of soxR (Superoxide response protein) and of $z w f$ (Glucose 6 phosphate dehydrogenase) 2 fold higher The oxygen shift did not increase the expression of the oxidant-resistant isozymes aconitase $\mathrm{A}$ and fumarase $\mathrm{C}$ which are encoded by the $a c n A$ and fum $C$ genes and the small regulatory RNA micF (Figure 4A). The transcription of genes under the control of OxyR regulon was notably less affected than those of the SoxRS regulon (Figure 4B). Transcription levels of $g r x A, d p s, a h p C$, and oxyS (whose products are glutaredoxin I, stress response DNA binding protein, alkyl hydroperoxide reductase, and regulatory RNA respectively), were increased no higher than 2 -fold.

Effect of high oxygen saturation on specific growth rate and gene transcription in the E. coli AB1157 and the double mutant strain sod $A^{-} \operatorname{sod}^{-}$

The effect of deleting the sod gene on the E. coli ability to respond to increase in oxygen concentration from 

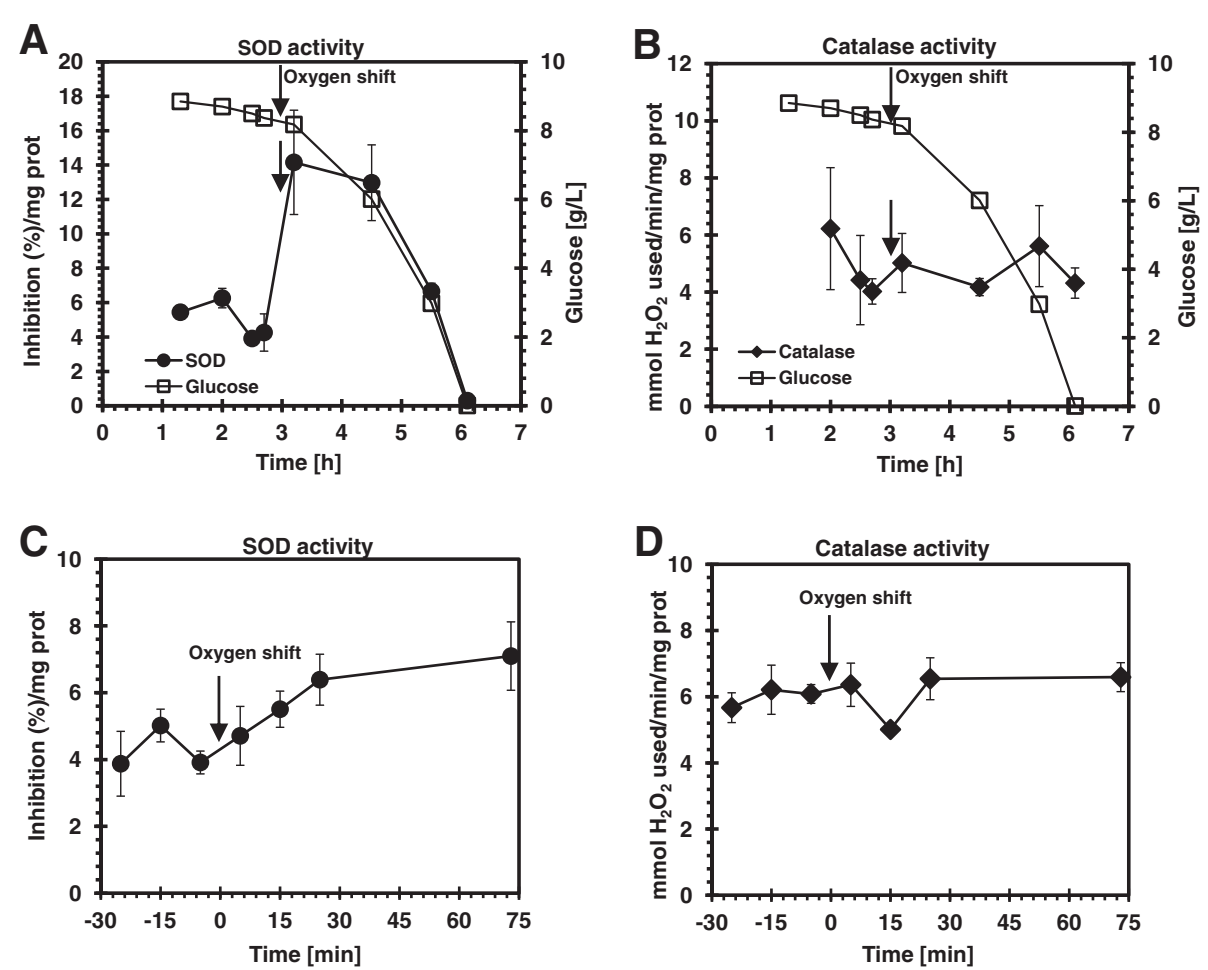

Figure 3 Superoxide dismutase (SOD) and catalase activity in E. coli MG1655 at $\mathbf{3 0 \%}$ and $\mathbf{3 0 0 \%} \mathbf{d O}_{\mathbf{2}}$. (A) SOD and (B) Catalase activity in a batch culture (C) SOD and (D) Catalase activity in a glucose-limited continuous culture ( $\mathrm{D}=0.5 \mathrm{~h}^{-1}$ ). The arrows indicate when $\mathrm{dO}_{2}$ was increased from $30 \%$ to $300 \%$. Error bars represent standard deviations between triplicate analyses of the same sample.

$30 \%$ to $300 \%$ was evaluated by following the growth patterns of the parental E. coli AB1157 strain and the double mutant strain PN134 $\left(\operatorname{sod} A^{-} \operatorname{sod} B^{-}\right)$. The growth patterns are shown in Figure 5; Figure 5A shows no effects of oxygen shift on the growth behavior of parental strain. The specific growth rates were $1.08 \mathrm{~h}^{-1}$ for the control growth and $1.06 \mathrm{~h}^{-1}$ for the culture expose to the increase in the $\mathrm{dO}_{2}$. On the other hand The SOD deficient strain was affected; following the $\mathrm{dO}_{2}$ shift its specific growth rate was reduced from $0.75 \mathrm{~h}^{-1}$ at $30 \%$ to $0.32 \mathrm{~h}^{-1}$ at high $\mathrm{dO}_{2}$ (Figure $5 \mathrm{~B}$ ).

Transcriptional analyses of the SoxRS regulon shows that the $\mathrm{dO}_{2}$ shift in the E. coli AB1157 increased the transcription of soxS by 16 fold, the transcription of $\operatorname{sod} A$ by 2.1 fold, but did not have any effect on the rest of the SoxRS-controlled genes (Figure 6A). The transcription analysis of the OxyR regulon shows that following the exposure to high $\mathrm{dO}_{2}$, the transcription of both $\operatorname{tr} x C$ and grxA increased by 2.2 fold and the transcription of oxyS by 3.7 fold (Figure 6B). Different patterns of gene expression were observed in the double mutant strain $\operatorname{sod} A^{-} \operatorname{sod} B^{-}$. In the SoxRS regulon, the genes that encode for the oxidantresistant isozymes, acnA and fum $C$, were up-regulated 3.4- and 10.2-fold respectively, suggesting that aconitase $B$ and fumarases A and B were inactivated by the oxidative stress. The expression of soxS in the double mutant strain increased by 32.5 fold following the change in $\mathrm{dO}_{2}$ which was significantly higher than the response observed in the E. coli AB1157 strain (Figure 6A, C). Concerning the transcription of the OxyR regulon, both kat $G$ and $\operatorname{tr} x C$ genes were up-regulated by 3.2 fold, whereas $g r x A$ and $d p s$ were up-regulated by 4 and 5.6 fold respectively (Figure 6D). Compared with the parental strain, the double mutant showed higher activity of SoxRS and OxyR transcriptional factors suggesting stronger oxidative stress response in this strain. To test if that could be due to a higher ROS accumulation in the double mutant, intracellular ROS concentrations were measured in parental and SOD deficient strains (Table 3). Although the ROS concentration was higher at $300 \% \mathrm{dO}_{2}$ than at $30 \%$ of $\mathrm{dO}_{2}$ there was no difference between the parental and the SOD deficient strain.

\section{Discussion}

It has been reported that exposing $E$. coli to reactive oxygen species (ROS), generated by chemical compounds such as $\mathrm{H}_{2} \mathrm{O}_{2}$ and paraquat, causes damage to the growing cells by reducing DNA stability and modifying proteins and lipids $[15,16,24]$. Since efficient growth of $E$. coli for production of recombinant proteins is based on growing the bacteria to high density by supplying air mixed with pure oxygen [3-5], it was 


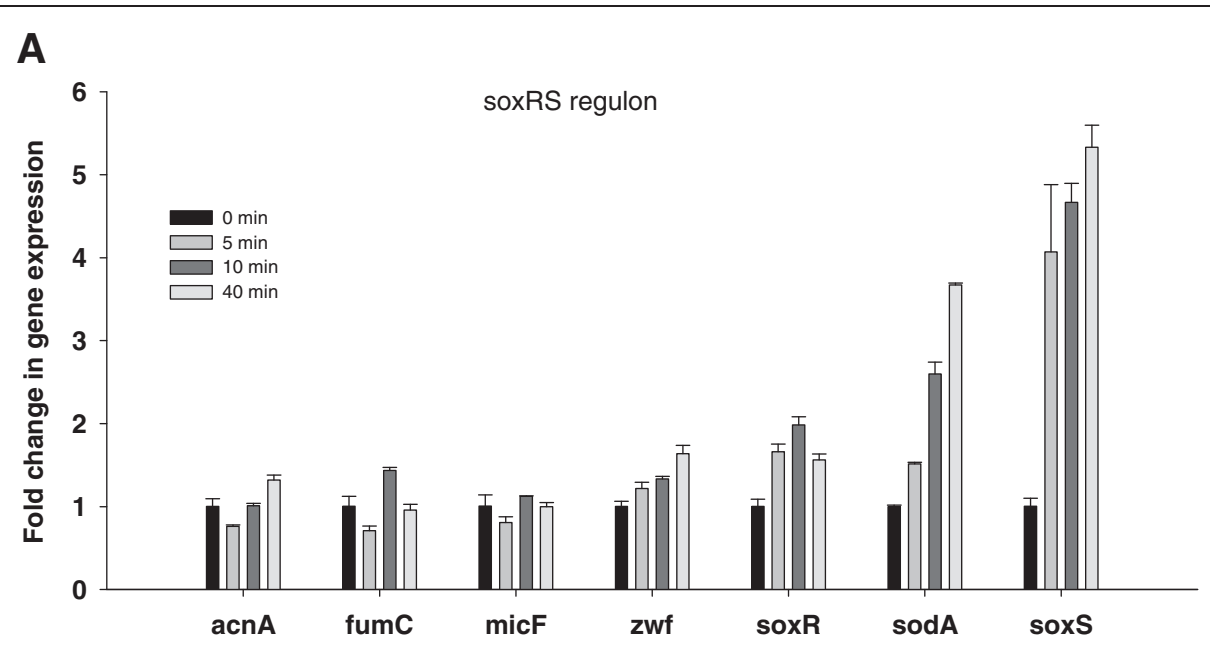

B

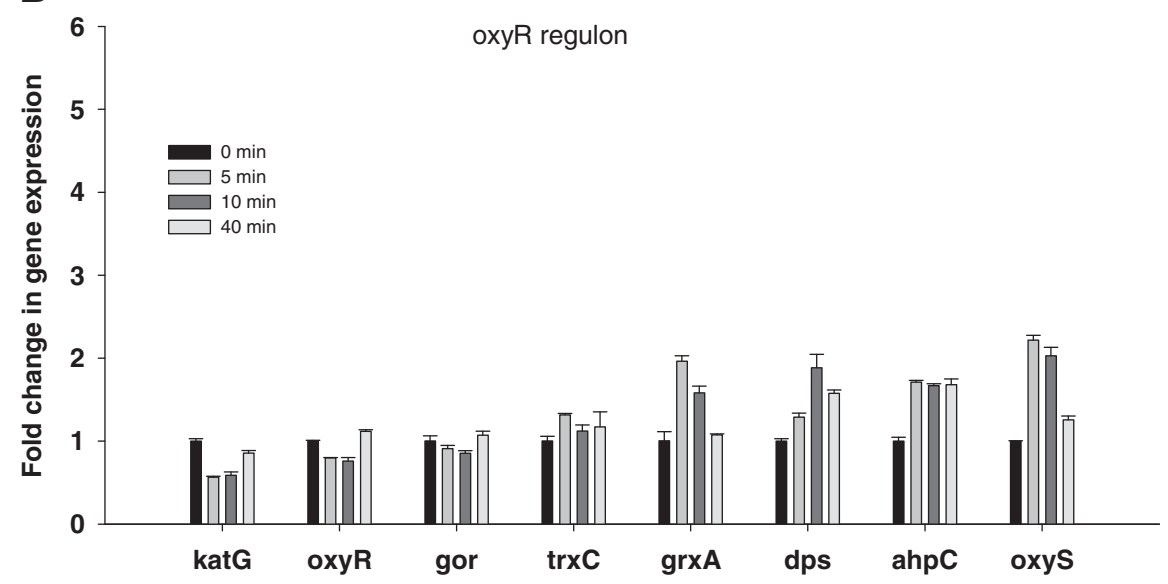

Figure 4 Time course expression of selected genes controlled by SoxRS and OxyR regulons during E. coli growth at $30 \%$ and $300 \%$ $\mathbf{d O}_{2}$. (A) SoxRS controlled genes, (B) OxyR controlled genes, changes in mRNA were analyzed $0,5,10$, and 40 min after $\mathrm{dO}_{2}$ shift from $30 \%$ to 300\% in E. coli MG1655. Error bars represent standard deviations between triplicate analyses.

essential to investigate the effect of high dissolved oxygen concentrations on bacterial growth.

The dissolved oxygen concentration is usually kept at $30 \% \mathrm{dO}_{2}$. In this reported work, the effect of higher dissolved oxygen concentrations on the bacterial growth and gene expression was evaluated. The data shows that $300 \% \mathrm{dO}_{2}$ did not affect the growth rate of the bacteria as a result of the activation of the manganese-superoxide dismutase (Mn-SOD), which is part of the activated SoxRS regulon. But high $\mathrm{dO}_{2}$ had small and short time effect on the respiration, the acetate accumulation, SOD activity and soxS expression suggesting sub-lethal damage to the E. coli culture.

A possible trigger for the activation of soxS expression is the high intracellular levels of $\mathrm{O}_{2}$ that stimulate SoxR oxidation by abstracting electrons from flavoenzymes and promoting the increased level of reactive oxygen species [15]. The increased ROS concentration decreased the $\mathrm{NADPH} / \mathrm{NADP}^{+}$ratio, which was suggested to be the signal for SoxRS activation $[19,25,26]$. It is also possible that hyperbaric oxygen ( 4.2 atm of $\mathrm{pO}_{2}$ ) blocks the synthesis and decreases intracellular concentrations of NAD and NADP $[21,27,28]$.

Hyperbaric oxygen destroys the [4Fe-4S] cluster in dihydroxyacid dehydratase (DHAD), and inactivates the enzyme [29]. Inactivated DHAD limits the biosynthesis of branched-chain amino acids and triggers stringent response $[30,31]$. In minimal medium without supplementation of amino acids, the inactivation of DHAD causes growth inhibition [31]. It is therefore likely that the oxidative stress generated in our study did not affect the DHAD activity since there was no significant change in the bacterial growth even when defined medium without supplementation of branched-chain amino acids was used. Hyperbaric oxygen also inactivates fumarase A and $\mathrm{B}$, both containing the catalytically active $4 \mathrm{Fe}-4 \mathrm{~S}$ cluster [29], but in our study the activity of these oxidantsensitive enzymes was not impaired by the $\mathrm{dO}_{2}$ shift 


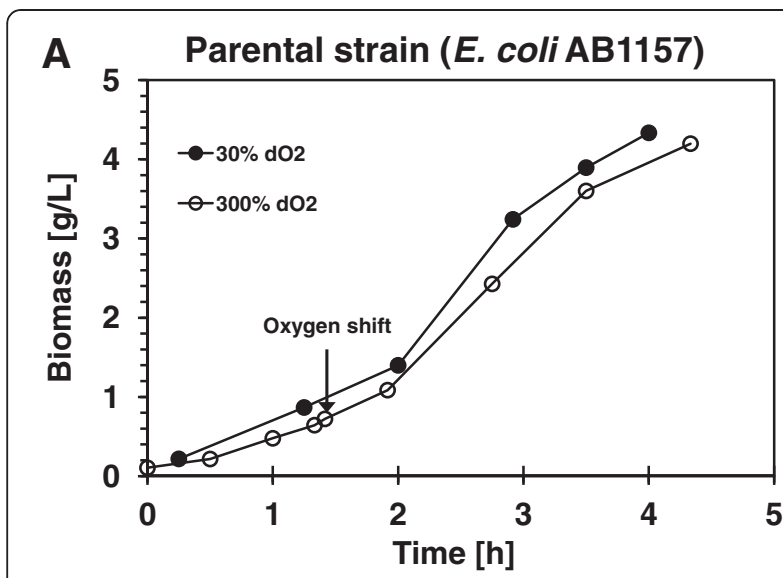

B

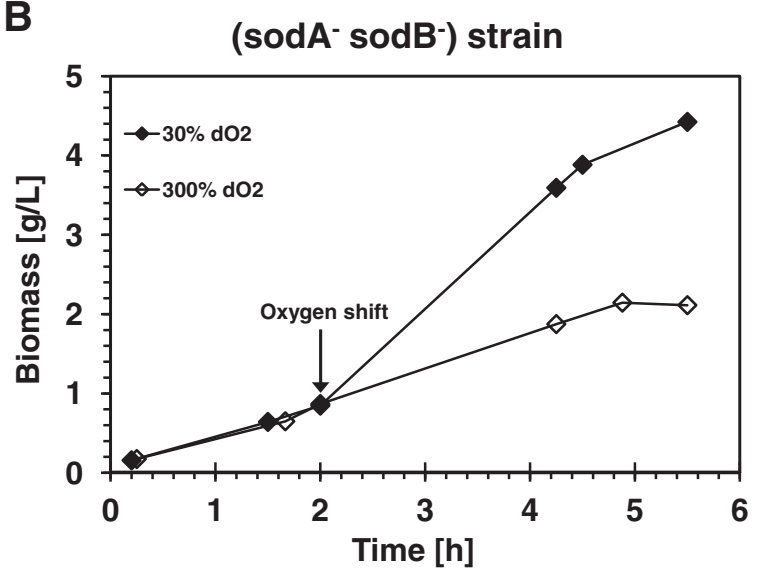

Figure 5 Effects of dissolved oxygen shift on growth of $E$. coli AB1157 and SOD deficient mutant. The arrows indicate when $\mathrm{dO}_{2}$ was increased from 30\% to 300\%. The reference culture was labeled as $30 \% \mathrm{dO}_{2}$ (solid symbols).

since the oxidant-resistant isozyme fumarase $C$ was not activated. These results could be explained by the protecting effects of superoxide dismutases on DHAD and fumarases $[29,30]$ and is in agreement with the upregulation of $\operatorname{sod} A$ and increased SOD activity. The same protecting effect of Mn-SOD on aconitase stability has been observed during exposure to hyperoxia [21] which could explain why the expression of the superoxideresistant aconitase A was not required.

Unlike the parental strain AB1157, the $\operatorname{sod} A^{-} \operatorname{sod} B^{-}$ strain requires the expression of the oxidant-resistant dehydratases, (aconitase A and fumarase $\mathrm{C}$ ) probably as the result of the inactivation of aconitase $\mathrm{B}$ and fumarase $\mathrm{A}$ and $\mathrm{B}$ by the presence of $\mathrm{O}_{2}^{-}[29,30]$. In our study the possible increased level of $\mathrm{O}_{2}^{-}$inside the deficient strain sod $A^{-} \operatorname{sod} B^{-}$activated also the OxyR-controlled genes, likely due to the production of extremely potent oxidants derived from ferric complexes and nitric oxide as a result of the missing SOD [32]. This assumption is supported by the fact that superoxide can reduce a variety of ferric complexes and increase the availability of $\mathrm{Fe}^{+2}$ which catalyzes Fenton and Haber-Weiss reactions $[16,32]$. The parental and the double mutant $\operatorname{sod} A^{-}$ $\operatorname{sod} B^{-}$strains did not show any difference in intracellular ROS accumulation. This is likely the result of the inability of the fluorimetric assay to detect differences in ROS concentrations in the range of $0.1 \mathrm{nM}$ [33] which is calculated to be the physiological concentration of superoxide [34]. However, the damage caused by this small change of superoxide in the SOD-deficient strain significantly affects its genes expression and growth.

Based on the presented work, we determined that $E$. coli can successfully prevent the toxic effects of high oxygen saturation through the activation of SoxRS and the over-expression of manganese-superoxide dismutase in response to increased concentration of intracellular ROS. The use of molecular oxygen in growing E. coli does not affect growth properties but because of the possible sub-lethal effects, its potential effects on quality of recombinant protein production and culture stability should be considered.

\section{Conclusions}

Increasing dissolved oxygen concentration during E. coli growth stimulates an increase in intracellular ROS concentration that activates the SoxRS regulon. The activation of the regulon is associated with over expression of manganese-superoxide dismutase that scavenges the $\mathrm{O}_{2}^{-}$ and prevents irreversible damage to the growing cells. SoxRS and SOD are identified as the main defense mechanism that protects the bacteria from the toxic effects of high oxygen saturation.

\section{Methods}

Bacterial strains, inoculum preparation, and culture media Escherichia coli MG1655 (F-, $\lambda$, ilvG-, rfb-50, rph-1) was grown in batch and continuous bioreactor cultivations in the following medium: $\mathrm{KH}_{2} \mathrm{PO}_{4}, 12.5 \mathrm{~g} / \mathrm{L} ;\left(\mathrm{NH}_{4}\right)_{2} \mathrm{HPO}_{4}$, $5 \mathrm{~g} / \mathrm{L}$; citric acid, $1.0 \mathrm{~g} / \mathrm{L}$. The $\mathrm{pH}$ of the medium was adjusted to 7.0 with $5 \mathrm{M} \mathrm{NaOH}$ prior to sterilization, after sterilization the media was aseptically supplemented with $1 \mathrm{~mL} / \mathrm{L}$ trace metal solution [3], $5 \mathrm{mM} \mathrm{MgSO}_{4}, 4.5 \mathrm{mg} / \mathrm{L}$ thiamine- $\mathrm{HCl}$, and $8 \mathrm{~g} / \mathrm{L}$ glucose. E. coli strains AB1157 (Parental), PN134 (sodA sodB deficient) provide by Dr. James A. Imlay [8] were grown in modified LB medium containing $10 \mathrm{~g} / \mathrm{L}$ tryptone, $5 \mathrm{~g} / \mathrm{L}$ yeast extract, $5 \mathrm{~g} / \mathrm{L}$ $\mathrm{NaCl}$, and $5 \mathrm{~g} / \mathrm{L} \mathrm{K}_{2} \mathrm{HPO}_{4}$, and supplemented with $1 \mathrm{~mL} / \mathrm{L}$ of trace metal solution, $5 \mathrm{mM} \mathrm{MgSO}, 4 \mathrm{~g} / \mathrm{L}$ of glucose and appropriate antibiotic after sterilization. Inoculums were prepared by growing the cultures at $37^{\circ} \mathrm{C}$ in $100 \mathrm{~mL}$ of defined or complex medium. 

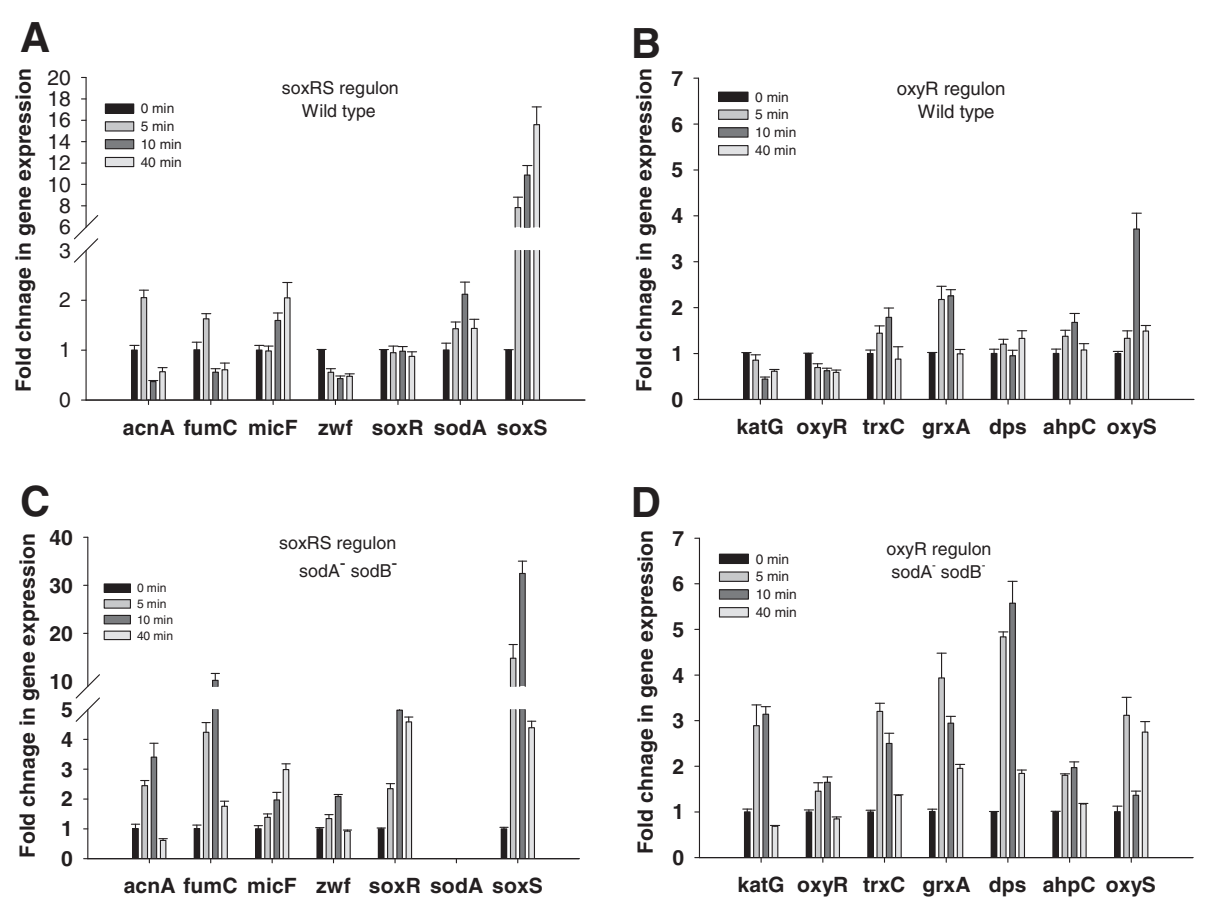

Figure 6 Time point expression of selected genes controlled by SoxRS and OxyR regulons in E. coli AB1157 and SOD deficient mutant. (A), (C) SoxRS-controlled genes, (B), (D) OxyR-controlled genes. Relative changes in mRNA were evaluated 0, 5, 10, and 40 min after dO ${ }_{2}$ increased from $30 \%$ to $300 \%$. Error bars represent standard deviations of three repetions.

\section{Bacterial growth}

Batch growth was performed in a $5 \mathrm{~L}$ B. Braun bioreactor equipped with data acquisition and adaptive dissolved oxygen control system. Temperature was maintained at $37^{\circ} \mathrm{C}$ and was maintained at $\mathrm{pH} 7.0$ by the addition of $3 \mathrm{M}$ $\mathrm{NaOH}$. Bioreactor was inoculated at $\mathrm{OD}_{600}$ of 0.1 and the dissolved oxygen $\left(\mathrm{dO}_{2}\right)$ was measured with polarographic oxygen electrode (Mettler Toledo, Columbus, $\mathrm{OH}$ ) and maintained at $30 \%$ air saturation. When the cell growth reached an $\mathrm{OD}_{600}$ of 1 the $\mathrm{dO}_{2}$ was increased to $300 \%$ air saturation by mixing the air supply with pure oxygen and was maintained at this value by increasing agitation and gas flow rate. $\mathrm{A} \mathrm{dO}_{2}$ of $300 \%$ air was chosen since it is equivalent to $63 \%$ of $\mathrm{O}_{2}$ in the inlet gas. Such oxygen

Table 3 Effects of dissolved oxygen on intracellular ROS concentration in $E$. coli

\begin{tabular}{lcc}
\hline & \multicolumn{2}{c}{ DFC production relative to $\mathbf{3 0 \%} \mathbf{~ d O}_{\mathbf{2}}$ condition } \\
\cline { 2 - 3 } & Parental (AB1157) & Deficient strain (sodA- sodB-) \\
\hline $\mathrm{N}_{2}$ & - & $0.45 \pm 0.042$ \\
$30 \% \mathrm{dO}_{2}$ & $1.00 \pm 0.029$ & $1.00 \pm 0.018$ \\
$300 \% \mathrm{dO}_{2}$ & $1.22 \pm 0.041$ & $1.22 \pm 0.048$ \\
$2 \mathrm{mM} \mathrm{H}_{2} \mathrm{O}_{2}$ & $2.71 \pm 0.138$ & $2.59 \pm 0.050$ \\
\hline
\end{tabular}

The data shown are the means and standard deviation of three determinations. concentration in the gas supply can be easily reached in a typical bench scale fed-batch culture [6].

The dissolved oxygen sensor used (InPro 6800 Mettler Toledo) was calibrated with nitrogen at zero and with pure $\mathrm{O}_{2}$ at $100 \%$. After calibration and before inoculation, air was bubbled into the medium to verify that the $\mathrm{dO}_{2}$ was $21 \%$. To maintain the culture at $30 \%$ air saturation, a set-point of $6 \%$ was set up and oxygen shift was made by changing the set-point to $63 \%$. The concentrations of $\mathrm{O}_{2}$ and $\mathrm{CO}_{2}$ in the inlet and outlet of the bioreactor were analyzed by mass spectrometry gas analyzer (Perkin Elmer MGA 1200). The analyzer performance was verified by pumping gas mixtures containing 21\%, $63 \%$ and $100 \% \mathrm{O}_{2}$, the values measured by gas analyzer were $21.4 \%, 63.6 \%$ and $98.5 \%$ respectively. In addition the $\mathrm{CO} 2$ measurement was verified with $5 \% \mathrm{CO}_{2}$. During the experiments at $300 \%$ DOT, oxygen concentration in the off gas varied from 62 to $64 \%$ and $\mathrm{CO}_{2}$ concentration did not exceed $3.4 \%$. Samples for RNA analysis were collected at $0,5,10$, and 40 minutes after the increase of the $\mathrm{dO}_{2}$ and processed immediately, media samples were collected at regular intervals and centrifuged at $10000 \times$ $\mathrm{g}$ for $5 \mathrm{~min}$ and the supernatant was kept at $-20^{\circ} \mathrm{C}$ for further analysis. The cell pellet was washed twice in $50 \mathrm{mM}$ sodium phosphate buffer $\mathrm{pH} 7.4$ and kept at $20^{\circ} \mathrm{C}$ for enzyme assays. The continuous culture was carried out at a dilution rate of $0.5 \mathrm{~h}^{-1}$ at the same growth 
conditions. After five residence times when steady state was confirmed the culture was perturbed by increasing the $\mathrm{dO}_{2}$ from $30 \%$ to $300 \%$ air saturation, samples for enzyme assays were taken 5, 15, 25 and 74 min after oxygen shift.

\section{Analytical methods}

Cell growth was followed by measuring the OD at $600 \mathrm{~nm}$ (Ultrospec 3000 UV/Visible spectrophotometer, Pharmacia Biotec); measurements were converted to dry cell weight by using a calibration curve of dried samples. Glucose concentration was determined by YSI 2700 Biochemistry Analyzer (YSI Instruments, Yellow Springs, OH). Organic acids were analyzed by high-performance liquid chromatography (Hewlett Packard/Agilent 1100 Series, Santa Clara, CA) with an Aminex HPX-87H column (Bio-Rad Laboratories, Hercules, $\mathrm{CA}$ ) at $35^{\circ} \mathrm{C}$ using mobile phase of $5 \mathrm{mM} \mathrm{H}_{2} \mathrm{SO}_{4}$ at $0.6 \mathrm{ml} / \mathrm{min}$.

\section{RT-qPCR analysis}

For real-time RT-qPCR determinations, fermentation samples were immediately poured on an ice-cooled tube containing RNAlater solution (Ambion Inc. Austin, TX). Total RNA extraction was performed using mirVana miRNA isolation kit (Ambion Inc. Austin, TX). Total RNA concentration was estimated by measuring optical density at $260 \mathrm{~nm}$ using NanoDrop 2000/2000c spectrophotometer (Thermo Fisher Scientific, Wilmington, DE) and integrity was visualized on a $2 \%$ agarose gels. To reduce genomic DNA contamination, isolated RNA was treated with turbo DNase kit (Ambion Inc. Austin, TX). cDNA was generated by using $2 \mu \mathrm{g}$ RNA in a total volume of $20 \mu \mathrm{l}$ with $250 \mathrm{nM}$ of specific DNA primers (antisense primers in Additional file 1: Table S1) according to the protocol of Maxima First Strand cDNA Synthesis kit (Thermo Fisher Scientific, Waltham, MA). Real-time qPCR was performed using an ABI Prism $7900 \mathrm{H}$ Sequence Detection System (Applied Biosystems, Foster City, CA) with 40 amplification cycles using SYBR Green PCR Master Mix as signal reporter. Each reaction composed of $6 \mathrm{ng}$ cDNA, $400 \mathrm{nM}$ sense and antisense primers in a total volume of $20 \mu \mathrm{l}$. RT-qPCR was done in a 96-well microtiter PCR plates using the following amplification conditions: 1 cycle $10 \mathrm{~min}$ at $95^{\circ} \mathrm{C}$; and 40 two-step cycle at $95^{\circ} \mathrm{C}$ for 15 seconds and $60^{\circ} \mathrm{C}$ for 60 seconds. Each sample was done in triplicate. To assess for reagent and genomic DNA contamination, no template and no reverse transcriptase controls were included. Data were analyzed using $2^{-\Delta \Delta C T}$ method described by Livak and Schmittgen [35]. The expression of the $s s r A$ gene was used as an endogenous control to normalize the amount of mRNA obtained from a target gene [36]. Expression data obtained for each time-point were normalized to the expression of each gene obtained at time zero of the oxygen switch.

\section{Cell-free extracts and enzymes assays}

Frozen cells were suspended in $300 \mu \mathrm{l}$ of $50 \mathrm{mM}$ sodium phosphate buffer $\left(\mathrm{pH} 7.4\right.$ at $\left.4{ }^{\circ} \mathrm{C}\right)$ and disrupted by sonication in series $4 \times 15$ seconds in a cold bath. The extract was centrifuged at $10,000 \times \mathrm{g}$ at $4^{\circ} \mathrm{C}$ for $15 \mathrm{~min}$ and the supernatant was immediately used for enzyme assays. Protein concentrations were determined by using the method of Bradford. Catalase activity was assayed spectrophotometrically by measuring the decrease in $\mathrm{A}_{240}$ $\mathrm{nm}$ of $4 \mathrm{mM} \mathrm{H}_{2} \mathrm{O}_{2}$ in $50 \mathrm{mM}$ phosphate buffer $\mathrm{pH} 7.4$ [37]. Superoxide dismutase activity was determined using the Sigma SOD assay kit-WST (Sigma-Aldrich, Switzerland) following the manufacturer's instructions.

\section{Measurement of intracellular level of ROS}

OxiSelect Intracellular ROS assay kit (Cell Biolabs, Inc. San Diego, CA) was used according to the manufacturer's instructions with minor modifications. AB1157 and PN134 strains growing in exponential phase were washed and incubated with 2', 7'-dichlorodihydrofluorescin diacetate for $60 \mathrm{~min}$ at $37^{\circ} \mathrm{C}$ and washed three times with PBS buffer. The 2,7'-dichlorofluorescein diacetate-loaded cells were resuspended in $2 \mathrm{ml} \mathrm{LB}$ media and then exposed to $2 \mathrm{mM}$ of $\mathrm{H}_{2} \mathrm{O}_{2}$ or bubbling with a gas mix corresponding to $0 \%$, $30 \%$, and $300 \% \mathrm{dO}_{2}$ air saturation for $20 \mathrm{~min}$. The treated cells were lysed and the amount of intracellular ROS was estimated from dichlorodihydrofluorescein (DCF) production measured at 480-nm excitation/530$\mathrm{nm}$ emission by a SpectraMax Gemini XS Fluorometer plate reader (Molecular Devices, Sunnyvale, CA).

\section{Additional file}

Additional file 1: Table $\mathbf{S 1}$. Set of primers used for quantitative realtime PCR amplification assays.

Competing interests

The authors declare that they have no competing interests.

\section{Authors' contributions}

$A B$ designed and conducted the experiments. $A B$ and JS together analyzed the data and wrote the manuscript. Both authors read and approved the final manuscript.

\section{Acknowledgement}

Funding was provided by the intramural program of the National Institute of Diabetes and Digestive and Kidney Diseases, National Institutes of Health. The authors would like to thank James Imlay (University of Illinois) for providing the AB1157 and PN134 strains, N. Majdalani (NCl, NIH) for the scientific advice and Mrs. D. Livnat for critical editorial assistance.

Received: 20 November 2012 Accepted: 21 February 2013

Published: 12 March 2013

\section{References}

1. Lee SY: High cell-density culture of Escherichia coli. Trends Biotechnol 1996, 14:98-105.

2. Shiloach J, Fass R: Growing E coli to high cell density-A historical perspective on method development. Biotechnol Adv 2005, 23:345-357. 
3. Bauer S, Shiloach J: Maximal exponential growth rate and yield of E. coli obtainable in a bench-scale fermentor. Biotechnol Bioeng 1974 16:933-941.

4. Castan A, Nasman A, Enfors SO: Oxygen enriched air supply in Escherichia coli processes: production of biomass and recombinant human growth hormone. Enzyme Microb Tech 2002, 30:847-854

5. Knoll A, Bartsch S, Husemann B, Engel P, Schroer K, Ribeiro B, Stockmann C, Seletzky J, Buchs J: High cell density cultivation of recombinant yeasts and bacteria under non-pressurized and pressurized conditions in stirred tank bioreactors. J Biotechnol 2007, 132:167-179.

6. Lara AR, Knabben I, Regestein L, Sassi J, Caspeta L, Ramirez OT, Buchs J: Comparison of oxygen enriched air vs. pressure cultivations to increase oxygen transfer and to scale-up plasmid DNA production fermentations. Eng Life Sci 2011, 3:1-5.

7. Storz G, Zheng M: Oxidative stress. In Bacterial stress responses. Edited by Storz G, Hengge-Aronis R. Wasington DC: ASM Press; 2000:47-59.

8. Gu M, Imlay JA: The SoxRS response of Escherichia coli is directly activated by redox-cycling drugs rather than by superoxide. Mol Microbiol 2011, 79:1136-1150.

9. Pomposiello PJ, Bennik MHJ, Demple B: Genome-wide transcriptional profiling of the Escherichia coli responses to superoxide stress and sodium salicylate. J Bacterio/ 2001, 183:3890-3902.

10. Zheng M, Wang X, Templeton LJ, Smulski DR, LaRossa R, Storz G: DNA microarray-mediated transcriptional profiling of the Escherichia coli response to hydrogen peroxide. J Bacterio/ 2001, 183:4562-4570.

11. Altuvia S, Weinstein-Fischer D, Zhang A, Postow L, Storz G: A small, stable RNA induced by oxidative stress: Role as a pleiotropic regulator and antimutator. Cell 1997, 90:43-53.

12. Ling J, Soll D: Severe oxidative stress induces protein mistranslation through impairment of an aminoacyl-tRNA synthetase editing site. Proc Natl Acad Sci USA 2010, 107:4028-4033.

13. Fridovich I: Oxygen toxicity: a radical explanation. J Exp Biol 1998, 201:1203-1209.

14. Fridovich I: Fundamental aspects of reactive oxygen species, or what's the matter with oxygen? Ann NY Acad Sci 1999, 893:13-18.

15. Imlay JA: Cellular defenses against superoxide and hydrogen peroxide. Annu Rev Biochem 2008, 77:755-776.

16. Farr SB, Kogoma T: Oxidative stress responses in Escherichia coli and Salmonella typhimurium. Microbiol Rev 1991, 55:561-585.

17. Demple B: Redox signaling and gene control in the Escherichia coli soxRS oxidative stress regulon- a review. Gene 1996, 179:53-57.

18. Fridovich I: Superoxide anion radical $\left(\mathrm{O}_{2}^{-}\right)$, superoxide dismutases, and related matters. J Biol Chem 1997, 272:18515-18517.

19. Liochev SI, Benov L, Touati D, Fridovich I: Induction of the soxRS regulon of Escherichia coli by superoxide. J Biol Chem 1999, 274:9479-9481.

20. Varghese S, Tang Y, Imlay JA: Contrasting sensitivities of Escherichia coli aconitases A and B to oxidation and iron depletion. J Bacterio/ 2003, 185:221-230.

21. Gardner PR, Fridovich I: Superoxide sensitivity of the Escherichia coli aconitase. J Biol Chem 1991, 266:19328-19333.

22. Liochev SI, Fridovich I: Fumarase C, the stable fumarase of Escherichia coli, is controlled by the soxRS regulon. Proc Natl Acad Sci 1992, 89:5892-5896.

23. Cunningham L, Gruer MJ, Guest JR: Transcriptional regulation of the aconitase genes (acnA and acnB) of Escherichia coli. Microbiology 1997, 143:3795-3805.

24. Keyer K, Gort AS, Imlay JA: Superoxide and the production of oxidative DNA damage. J Bacteriol 1995, 177:6782-6790.

25. Gaudu P, Dubrac S, Touati D: Activation of SoxR by overproduction of desulfoferrodoxin: Multiple ways to induce the soxRS regulon. J Bacteriol 2000, 182:1761-1763.

26. Krapp AR, Humbert MV, Carrillo N: The soxRS response of Escherichia coli can be induced in the absence of oxidative stress and oxygen by modulation of NADPH content. Microbiology 2011, 157:957-965.

27. Brown OR, Yein F, Boehme D, Foudin L, Song CS: Oxygen poisoning of NAD biosynthesis: A proposed site of cellular oxygen toxicity. Biochem Biophys Res Commun 1979, 91:982-990.

28. Draczynska-Lusiak B, Brown OR: Proetein A of quinolinate synthetase is the site of oxygen poisoning of pyridine nucleotide coenzyme synthesis in Escherichia coli. Free Radic Biol Med 1992, 13:689-693.
29. Flint DH, Tuminello JF, Emptage MH: The inactivation of Fe-S cluster containing hydro-lyases by superoxide. J Biol Chem 1993, 268:22369-22376.

30. Brown OR, Smyk-Randall E, Draczynska-Lusiak B, Fee JA: Dihydroxy-acid dehydratase, a [4Fe-4S] cluster-containing enzyme in Escherichia coli: Effects of intracellular superoxide dismutase on its inactivation by oxidant stress. Arch Biochem Biophys 1995, 319:10-22.

31. Brown OR, Yein F: Dihydroxyacid dehydratase: the site of hyperbaric oxygen poisoning in branch-chain amino acid biosynthesis. Biochem Biophys Res Commun 1978, 85:1219-1224.

32. Fridovich I, Freeman B: Antioxidant defenses in the lung. Ann Rev Physiol 1986, 48:693-702.

33. Dirmeier R, O'Brien KM, Engle M, Dodd A, Spears E, Poyto RO: Exposure of yeast cells to anoxia induces transient oxidative stress. J Biol Chem 2002, 277:34773-34784.

34. Gort AS, Imlay JA: Balance between endogenous superoxide stress and antioxidant defenses. J Bacteriol 1998, 180:1402-1410.

35. Livak KJ, Schmittgen TD: Analysis of relative gene expression data using real-time quantitative PCR and the 2(-Delta Delta $C(T)$ ) method. Methods 2001, 25:402-408

36. Moon K, Gottesman S: A pho Q/P-regulated small RNA regulates sensitivity of Escherichia coli to antimicrobial peptides. Mol Microbiol 2009, 74:1314-1330.

37. Gonzalez-Flecha B, Demple B: Role for the oxyS gene in regulation of intracellular hydrogen peroxide in Escherichia coli. J Bacteriol 1999, 181:3833-3836.

doi:10.1186/1475-2859-12-23

Cite this article as: Baez and Shiloach: Escherichia coli avoids high dissolved oxygen stress by activation of SoxRS and manganesesuperoxide dismutase. Microbial Cell Factories 2013 12:23.

\section{Submit your next manuscript to BioMed Central and take full advantage of:}

- Convenient online submission

- Thorough peer review

- No space constraints or color figure charges

- Immediate publication on acceptance

- Inclusion in PubMed, CAS, Scopus and Google Scholar

- Research which is freely available for redistribution 